University of Nebraska - Lincoln

DigitalCommons@University of Nebraska - Lincoln

Roman L. Hruska U.S. Meat Animal Research

U.S. Department of Agriculture: Agricultural Center

Research Service, Lincoln, Nebraska

1982

\title{
Elfazepam and Synovex-S Influences on Growth and Carcass Characteristics of Steers Fed Two Dietary Energy Levels
}

\author{
Ronald L. Prior \\ U.S. Meat Animal Research Center \\ John D. Crouse \\ U.S. Meat Animal Research Center \\ Virden L. Harrison \\ U.S. Meat Animal Research Center
}

Follow this and additional works at: https://digitalcommons.unl.edu/hruskareports

Part of the Animal Sciences Commons

Prior, Ronald L.; Crouse, John D.; and Harrison, Virden L., "Elfazepam and Synovex-S Influences on Growth and Carcass Characteristics of Steers Fed Two Dietary Energy Levels" (1982). Roman L. Hruska U.S. Meat Animal Research Center. 11.

https://digitalcommons.unl.edu/hruskareports/11

This Article is brought to you for free and open access by the U.S. Department of Agriculture: Agricultural Research Service, Lincoln, Nebraska at DigitalCommons@University of Nebraska - Lincoln. It has been accepted for inclusion in Roman L. Hruska U.S. Meat Animal Research Center by an authorized administrator of DigitalCommons@University of Nebraska - Lincoln. 


\section{ELFAZEPAM AND SYNOVEX-S INFLUENCES ON GROWTH AND CARCASS CHARACTERISTICS OF STEERS FED TWO DIETARY ENERGY LEVELS}

Ronald L. Prior, ${ }^{1}$ John D. Crouse, and Virden L. Harrison

\section{Summary}

Synovex-S improves the average daily gain and carcass traits of steers and reduces losses under high feed price levels when compared to nonimplanted steers. High energy diets also influence average daily gain (ADG) favorably, but they increase the amount of fat and decrease the protein in carcass soft tissue in comparison to low energy diets.

\section{Introduction}

Under present market conditions, the use of growth-promoting implants or feed additives that improve gain or feed efficiency can be the difference between profit and loss in many feeding operations. Synovex-S (200 mg of progesterone and $20 \mathrm{mg}$ of estradiol benzoate) improves ADG and feed efficiency in steers.

The use of stimulants in feed intake may have desirable effects on the performance of growing animals, particularly where voluntary intake is not adequate to provide sufficient net energy for gain. Alkyl-sulfonylalkyl-1- substituted benzodiazepines have been shown to elicit feeding in satiated animals. Voluntary intake is of particular concern in high-

${ }^{1}$ Ronald L. Prior is a research chemist at MARC. roughage diets where intake is limited by fill. In addition to the feeding response elicited by Elfazepam, it has been reported that administering Elfazepam to sheep fed a constant amount of feed increased the digestibility of the diet.

\section{Procedure}

The objectives of this study were to determine the effect of Elfazepam on growth and carcass characteristics of steers fed rations of two energy densities with corn silage as the forage base and to study possible interactions with Synovex$\mathrm{S}$ implants. Corn silage represented $81.7 \%$ of the dry matter in the low energy diets and $19.7 \%$ in the high energy diets, resulting in 5.7 and $6.8 \mathrm{Mcal}$ metabolizable energy per pound for the two diets. Elfazepam was added to the diet to provide about $8 \mathrm{mg} / \mathrm{head} / \mathrm{day}$. Steers were fed to $1,122 \mathrm{lb}$ pen mean weights. Adding Elfazepam to the diet decreased rate of gain of steers by $9 \%$ compared to controls not receiving Elfazepam.

\section{Results}

Steers implanted with Synovex-S had a $27 \%$ greater ADG, a heavier hot carcass weight, and less kidney and pel- vic fat than nonimplanted steers (Table 1) The trend toward a decreased quality grade from Synovex-S implant in the present experiment approached statistical significance. We noted no significant two-way interactions between dietary energy level, Synovex-S implant, or Elfazepam in growth or carcass composition traits.

The effect of Synovex-S implants was highly significant both from a biological and an economic standpoint. These implants made the difference between profits and losses under the low feed price level and reduced the losses under the high feed price level. Although Synovex-S resulted in similar yield grades and lower quality grades, this lowering of steer value per $220 \mathrm{lb}$ was offset by a $27 \%$ increase in ADG. Under the low feed price level, net returns per steer per day were $\$ 0.113$ higher for steers implanted with Synovex$S$ than for nonimplanted steers.

Ration energy level significantly influenced ADG. Steers fed the high energy diet had more kidney and pelvic fat and more estimated fat and less protein in carcass soft tissue than steers fed the low energy diet. The other carcass traits measured were not significantly influenced by dietary energy levels.

Table 1.-Main effects of Elfazepam, Synovex-S implant, and dietary energy level on steer performance and carcass traits ${ }^{1}$

\begin{tabular}{|c|c|c|c|c|c|c|c|c|c|c|c|c|}
\hline \multirow[b]{2}{*}{ Item } & \multicolumn{4}{|c|}{ Elfazepam } & \multicolumn{4}{|c|}{ Synovex-S implant } & \multicolumn{4}{|c|}{ Dietary energy level } \\
\hline & - & & + & & - & & + & & Low & & High & \\
\hline Number of steer & 109 & & 108 & & 107 & & 110 & & 110 & & 107 & \\
\hline Initial & $765.4 \pm$ & 4.4 & $762.3 \pm$ & 4.4 & $764.9 \pm$ & 4.6 & $762.7 \pm$ & 4.2 & $765.2 \pm$ & 4.4 & $762.5 \pm$ & 4.4 \\
\hline Slaughter weic & $1119.1 \pm$ & 7.0 & $1120.0 \pm$ & 7.01 & $1079.1 \pm$ & ${ }^{2} 7.31$ & $1160.1 \pm$ & ${ }^{3} 6.81$ & $1135.2 \pm$ & ${ }^{3} 7.0$ & $1102.0 \pm$ & ${ }^{2} 7.0$ \\
\hline Days on feed & $134.3 \pm$ & 24.1 & $144.8 \pm$ & 20.2 & $139.5 \pm$ & 14.7 & $139.5 \pm$ & 14.7 & $164.5 \pm$ & 20.4 & $115.5 \pm$ & 13.1 \\
\hline Overall averag & $2.79 \pm$ & ${ }^{3} .04$ & $2.55 \pm$ & ${ }^{2} .04$ & $2.35 \pm$ & ${ }^{2} .04$ & $2.99 \pm$ & ${ }^{3} .04$ & $2.31 \pm$ & ${ }^{2} .04$ & $3.04 \pm$ & 3.04 \\
\hline Hot carcass wei & $666.8 \pm$ & 4.8 & $673.0 \pm$ & 4.8 & $674.0 \pm$ & ${ }^{2} 5.1$ & $692.8 \pm$ & ${ }^{3} 4.8$ & $672.8 \pm$ & 4.8 & $667.3 \pm$ & 5.1 \\
\hline Adjusted fat thickness & $.46 \pm$ & .02 & $.43 \pm$ & .02 & $.44 \pm$ & .02 & $.44 \pm$ & .02 & $.43 \pm$ & .02 & $.46 \pm$ & .02 \\
\hline Longissimus area ... & $12.2 \pm$ & .2 & $11.9 \pm$ & .2 & $12.2 \pm$ & .2 & $11.9 \pm$ & .2 & $12.0 \pm$ & .2 & $12.2 \pm$ & .2 \\
\hline and pelvic $f$ & $2.95 \pm$ & .08 & $2.78 \pm$ & .08 & $2.99 \pm$ & ${ }^{3} .09$ & $2.74 \pm$ & ${ }^{2} .08$ & $2.76 \pm$ & ${ }^{2} .08$ & $2.97 \pm$ & ${ }^{3} .08$ \\
\hline Marbling ${ }^{4}$. & $10.57 \pm$ & .37 & $10.76 \pm$ & .36 & $11.18 \pm$ & .42 & $10.16 \pm$ & .35 & $11.10 \pm$ & .36 & $10.24 \pm$ & .37 \\
\hline Quality grade ${ }^{5}$ & $9.45 \pm$ & .19 & $9.50^{\circ} \pm$ & .19 & $9.70 \pm$ & .22 & $9.25 \pm$ & .18 & $9.61 \pm$ & .18 & $9.35 \pm$ & .19 \\
\hline $\begin{array}{l}\text { Yield grade } \\
\text { Estimated soft ti }\end{array}$ & $2.94 \pm$ & .10 & $2.90 \pm$ & .10 & $2.90 \pm$ & .12 & $2.94 \pm$ & .10 & $2.93 \pm$ & .10 & $2.91 \pm$ & .10 \\
\hline Fat. & $35.00 \pm$ & ${ }^{3} .51$ & $33.81 \pm$ & ${ }^{2} .51$ & $33.90 \pm$ & .5 & $8 \pm$ & .49 & $33.23 \pm$ & ${ }^{2} .50$ & $35.58 \pm$ & ${ }^{3} .52$ \\
\hline Prote & $14.30 \pm$ & 2.14 & $14.78 \pm$ & ${ }^{3} .14$ & $14.73 \pm$ & ${ }^{3} .16$ & $14.36 \pm$ & 2.13 & $15.06 \pm$ & 3.13 & $14.03 \pm$ & 2.14 \\
\hline Moisture & $50.96 \pm$ & .38 & $51.47 \pm$ & .38 & $50.89 \pm$ & .44 & $51.53 \pm$ & .36 & $51.18 \pm$ & .37 & $51.24 \pm$ & .39 \\
\hline
\end{tabular}

1 Data presented as least-squares means \pm standard error of the mean. Carcass quality and composition traits were adjusted by analysis of covariance to a hot carcass weight of $685.3 \mathrm{lb}$.

2,3 Means within a treatment without a common superscript differ $\left(\mathrm{P}_{x}, 05\right)$.

${ }^{4}$ Marbling score: slight $=7,8,9 ;$ small $=10,11,12$.

${ }^{5}$ Quality grade score: good $=7,8,9$; choice $=10,11,12$ 